\title{
The Characteristics of Heavy Ozone Pollution Episodes and Identification of the Primary Driving Factors Using a Generalized Additive Model (GAM) in an Industrial Megacity of Northern China
}

\author{
Liuli Diao, Xiaohui Bi *, Wenhui Zhang, Baoshuang Liu, Xuehan Wang, Linxuan Li, Qili Dai ${ }^{\circ}$, Yufen Zhang, \\ Jianhui Wu and Yinchang Feng
}

check for updates

Citation: Diao, L.; Bi, X.; Zhang, W.; Liu, B.; Wang, X.; Li, L.; Dai, Q.; Zhang, Y.; Wu, J.; Feng, Y. The Characteristics of Heavy Ozone Pollution Episodes and Identification of the Primary Driving Factors Using a Generalized Additive Model (GAM) in an Industrial Megacity of Northern China. Atmosphere 2021, 12, 1517. https://doi.org/10.3390/atmos12111517

Academic Editor: Begoña Artíñano

Received: 14 October 2021

Accepted: 11 November 2021

Published: 17 November 2021

Publisher's Note: MDPI stays neutral with regard to jurisdictional claims in published maps and institutional affiliations.

Copyright: (C) 2021 by the authors. Licensee MDPI, Basel, Switzerland. This article is an open access article distributed under the terms and conditions of the Creative Commons Attribution (CC BY) license (https:/ / creativecommons.org/licenses/by/ $4.0 /)$.
State Environmental Protection Key Laboratory of Urban Ambient Air Particulate Matter Pollution Prevention and Control, College of Environmental Science and Engineering, Nankai University, Tianjin 300350, China; 2120190639@mail.nankai.edu.cn (L.D.); zhangwh@mail.nankai.edu.cn (W.Z.); lbsnankai@foxmail.com (B.L.); xh.wang@mail.nankai.edu.cn (X.W.); lilinxuan@mail.nankai.edu.cn (L.L.); daiql@nankai.edu.cn (Q.D.); zhafox@nankai.edu.cn (Y.Z.); envwujh@nankai.edu.cn (J.W.); fengyc@nankai.edu.cn (Y.F.)

* Correspondence: bixh@nankai.edu.cn

Abstract: Tropospheric ozone is the only normal pollutant with a continuously increasing annual average concentration worldwide. In this study, data were monitored at the Nankai University Air Quality Research Supersite (NKAQRS) $\left(38.99^{\circ} \mathrm{N}, 117.33^{\circ} \mathrm{E}\right)$ between 1 April, and 31 August from 2018 to 2020, $33 \mathrm{O}_{3}$ episodes from 2018 to 2020 were analyzed to reveal the characteristics of $\mathrm{O}_{3}$, VOCs and OFP during $\mathrm{O}_{3}$ episodes and to evaluate the driving factors. The $\mathrm{O}_{3}$ episodes showed a decreasing trend in terms of pollution frequency, days, heavy pollution duration and peak concentration. Ethane, acetylene, cyclopentane, and methylcyclopentane were the major types in 2020, while 1-hexene was the main component in 2019. The main ozone-contributing species in 2020 were propene cyclopentane methylcyclopentane and ethylene. Alkenes were important contributors to ozone formation. Using generalized additive models (GAMs), the explanatory variables in the study are divided into environmental and meteorological factors, and 16 impact factors are selected as explanatory variables. We found that the influence of these meteorological factors on $\mathrm{O}_{3}$ pollution was nonlinear and impacted by the interaction between variables. $\mathrm{O}_{3}$ episodes were mainly driven by meteorological and precursor (NO) factors in 2018, while meteorological conditions (T), followed by precursor $\left(\mathrm{NO}_{2}\right)$ were the driving factors in 2019 and 2020, suggesting that $\mathrm{O}_{3}$ episodes were mainly driven by meteorological conditions.

Keywords: $\mathrm{O}_{3}$ episodes; OFP; GAM; driving factors

\section{Introduction}

Tropospheric ozone is a normal pollutant with a continuously increasing annual average concentration in the mainland China [1]. Ozone affects the healthy growth of plants, leading to a decline in crop yields, and is also hazardous to the human respiratory system, organs, immune system and tissues, which threatens health and even human life [2-6]. Tropospheric ozone $\left(\mathrm{O}_{3}\right)$ is mainly produced by the photochemical reaction of its precursors (NOx, VOCs et al.) under favorable meteorological conditions [7-10]. The concentration of ambient $\mathrm{O}_{3}$ always shows a nonlinear correlation with these precursors, suggesting a complex physicochemical mechanism in the ozone formation process [11-14].

As key precursors of $\mathrm{O}_{3}$ pollution, volatile organic compounds (VOCs) can be transmitted over long distances [15], and they are mostly toxic [16,17] and carcinogenic [16,17]. Under UV irradiation, VOCs react with NOx to generate ozone and enhance atmospheric oxidation $[18,19]$. They are one of the main contributors to regional air pollution in recent 
years [20,21]. Meteorological factors also play an important role in ozone formation, dilution, diffusion and transportation [22], including temperature, humidity, solar radiation and wind $[8,23-26]$. Studies have shown that high ozone levels are usually related to strong solar radiation, high temperature, low wind speed, low or least rainfall, and low relative humidity [27-29].

Due to the nonlinearity between ozone pollution and its precursors, it is difficult to effectively control ozone pollution. It is necessary to evaluate the relationship between $\mathrm{O}_{3}$ episodes and its influencing factors and to identify the major factors. The common nonlinear methods are the convergent cross mapping (CCM) method [30], the generalized additive model (GAM), and the Observation-Based Model (OBM) [31]. Compared to traditional nonlinear statistical models, the Generalized Additive Model (GAM) can directly deal with the complex nonlinear relationships between multiple response and explanatory variables, can introduce nonlinear and nonmonotonic variables into the analysis [32], and is widely used to identify impact factors and evaluate the nonlinear relationship related to air pollution $[33,34]$, and is a better method for evaluating the nonlinear relationship between influencing factors and air pollution. Gong et al. [35] used GAM to quantify the impact of individual meteorological conditions on $\mathrm{O}_{3}$ pollution in 16 Chinese cities, emphasizing that the model can explain the relationship between meteorological conditions and $\mathrm{O}_{3}$ concentration. Kim and Hong [36] used a multiple linear regression model and GAM to study the response of $\mathrm{O}_{3}$ pollution to meteorological factors (i.e., wind speed, temperature and humidity) in Seoul, South Korea. Although a great deal of research has been conducted, it is still challenging to fully understand the impact of meteorology on ozone concentration. First, previous studies have mainly considered meteorological conditions and the effect of precursors on ozone concentrations, among them, VOCs instead of alkenes, alkanes, aromatics, and acetylene are used as explanatory variables in GAM. Secondly, since different meteorological factors interact closely, and most of them are nonlinear relationships, commonly used correlation analyses may lead to biased results [37]. Therefore, this study refines VOCs into alkenes, alkanes, aromatics and acetylene, and incorporates all factors that affect ozone formation such as meteorological conditions and precursors in the GAM model to quantify the impact of various influencing factors on ozone pollution.

The regional study by Lu et al. [38] pointed out that compared with other industrialized regions in the world, China's short-term and long-term human exposure to and plant damage by ozone were severe. Ozone pollution becoming the key pollutant in summer of northern China has attracted increasing attention. $\mathrm{O}_{3}$ episodes often occur in the form of pollution processes that continue for several hours or even days. It is of great value to analyze the process of $\mathrm{O}_{3}$ episodes to understand the fluctuation law of ozone pollution. Currently, most of these studies have mainly focused on the North China Plain, Yangtze River Delta, and Pearl River Delta regions [30,39-42]. The studies of the relationships between $\mathrm{O}_{3}$ episodes and the influencing factors are rarely reported. Tianjin is an important economic center and a densely populated urban agglomeration area in northern China $[43,44]$, therefore we focused on Tianjin in this study. The purposes of this study are as follows: 1 -Analyze changes in $\mathrm{O}_{3}$ episodes between 1 April and 31 August from 2018 to 2020 in Tianjin and the differences in the concentrations of VOCs and OFP in different years. 2-Analyze the main influencing factors (including precursors, meteorological factors, etc.) of $\mathrm{O}_{3}$ episodes in different years through the GAM model, and determine the main driving factors of $\mathrm{O}_{3}$ episodes.

\section{Methods and Materials}

\subsection{Site Description}

VOCs data were monitored at the Nankai University Air Quality Research Supersite (NKAQRS) $\left(38.99^{\circ} \mathrm{N}, 117.33^{\circ}\right.$ E) between 1 April, and 31 August from 2018 to 2020, which is located on the Nankai University campus in the Jinnan Distinct, Tianjin (Figure 1). A student dormitory area is located to the south of the NKAQRS, and a road with relatively 
low traffic flow is sited $20 \mathrm{~m}$ to the north. Easterly and southeasterly winds prevailed during the study period. According to Chinese National Ambient Air Quality Standard and Technical Regulation on Ambient Air Quality Index (AQI) of China (MEE, 2012a), we define an $\mathrm{O}_{3}$ episode as one day or a set of continuous days longer than 2 days with a maximum daily $8 \mathrm{~h}$ average (MDA8) ozone concentration exceeding $160 \mu \mathrm{g} \mathrm{m}^{-3}$. A day with mean ozone values of the maximum daily $8 \mathrm{~h}$ average (MDA8) exceeding $160 \mu \mathrm{g} \mathrm{m}^{-3}$ is defined as a high- $\mathrm{O}_{3}$ day. The mean wind speed (ws), temperature (T) and the relative humidity (RH) were $1.6 \pm 1.1 \mathrm{~m} / \mathrm{s}, 23.7 \pm 6.5^{\circ} \mathrm{C}, 64.4 \pm 23.1 \%$, respectively during $\mathrm{O}_{3}$ episodes. The meteorological conditions and pollutants were shown in Table S1.

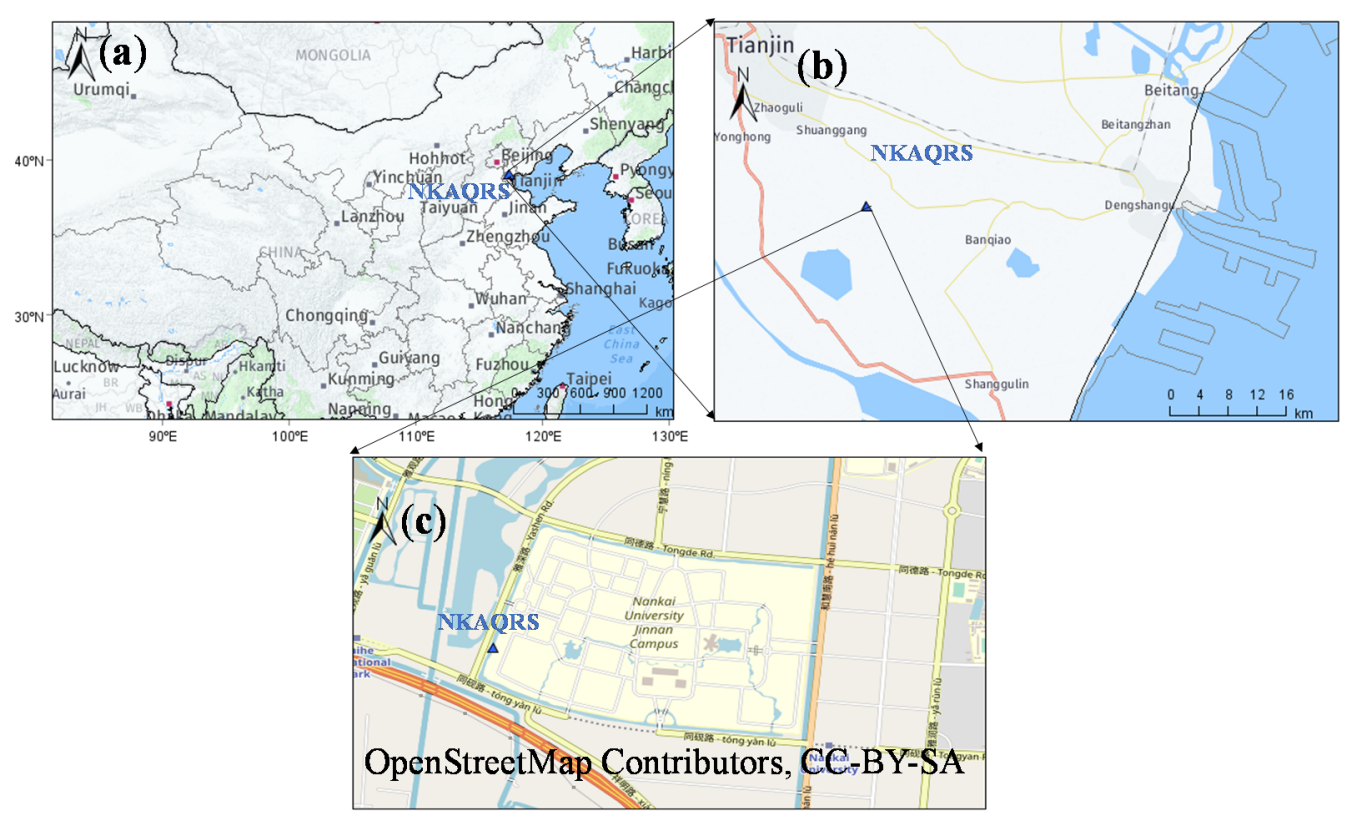

Figure 1. Map of monitoring site in Tianjin. (a) Geographical location of Tianjin city (b) Geographical location of Nankai University Air Quality research Supersite(c) Map of Nankai University.

\subsection{Species Monitoring}

VOC-species data were continuously monitored at intervals of $1 \mathrm{hr}$ using a GC955 series 611/811 VOC analyzer (Syntech Spectras Inc., Groningen, the Netherlands). In total, 54 VOC species designated as photochemical precursors by the United States Environmental Protection Agency (US EPA) were monitored and used in the premonitoring equipment calibration. The analyses were performed using a photo (PID) and a flame (FID) ionization detector, which ensured high sensitivity and effective identification. The GC955 series 611 and 811 devices are two separated sample and column systems, which measure high (C6$\mathrm{C} 10)$ and low (C2-C5) boiling-point VOC species, respectively. For the series 811, the C2-C5 VOC species in ambient air were preconcentrated on Carbosieves SIII at a temperature of $-5^{\circ} \mathrm{C}$. The enriched compounds were then thermally desorbed by heating (to $270{ }^{\circ} \mathrm{C}$ ) and were purged into the separation column. The target compounds were then detected by the PID and an FID. The Series 611 was used to determine C6-C10 VOC-species. Air samples were preconcentrated on Tenax GR at ambient atmospheric temperature $\left(\sim 30^{\circ} \mathrm{C}\right)$. Target compounds were then desorbed at $230^{\circ} \mathrm{C}$, brought into a stripper column, and then an analysis column for separation and a PID for detection. Quality assurance and quality control measures were performed, including routine maintenance of the instrument every week, fortnightly five-point calibration and verification, daily single-point correction, and weekly filter replacement. The analyzer was calibrated using standard gas to determine the retention times and control peak areas; correlation coefficient typically varied between 0.900 and 1.000. The method detection limits (MDL) for VOC species ranged from 0.019 to 0.599 ppbv. In accordance with the detection results, we obtained data for 54 VOC species 
within four VOC subcategories. Wind roses during the study period are given in Figure S1 in the Supplementary Materials. The data were subject to strict quality control measures, and abnormal data were excluded from the analysis.

$\mathrm{SO}_{2}, \mathrm{NO}_{2}$, $\mathrm{CO}$ data were obtained from $\mathrm{SO}_{2}$ analyzer (API., Baltimore, ML, USA), NOx analyzer (API., Baltimore, ML, USA), CO analyzer (API., Baltimore, ML, USA) in the Nankai University Air Quality research Supersite $\left(38^{\circ} 59^{\prime} \mathrm{N}, 117^{\circ} 20^{\prime} \mathrm{E}\right)$ in the Jinnan district of Tianjin, China.

\subsection{Methods}

\subsubsection{Ozone Formation Potential (OFP)}

The maximum incremental reactivity (MIR) method proposed by Carter [45] is widely used as a good indicator for comparing the ozone formation potential (OFP) of individual VOC species, and has been used to evaluate the photochemical reactivity of VOCs with $\mathrm{OH}$ radicals and for estimation of the contribution of individual organic compounds to ozone formation, and it is defined as follows:

$$
\begin{gathered}
\mathrm{OFP}_{\mathrm{i}}=\mathrm{MIR}_{\mathrm{i}} \times \mathrm{C}_{\mathrm{i}} \\
\mathrm{OFP}=\sum \mathrm{OFP}_{\mathrm{i}}
\end{gathered}
$$

Here, $[V O C]_{i}$ is the concentration of VOC species $i, \mathrm{OFP}_{\mathrm{i}}$ is defined as the ozone formation potential of individual species $i, M_{i}$ is defined as the maximum incremental reactivity coefficient for individual species $i$, which is updated by Carter [46]. Additionally, OFP is defined as the ozone formation potential of the total species.

\subsubsection{GAM}

GAM have a nonlinear relationship between the corresponding variables and predictors using a smooth function,

$$
\mathrm{g}\left(\mathrm{u}_{\mathrm{i}}\right)=\mathrm{a}_{0}+\mathrm{f}_{1}\left(\mathrm{x}_{1 \mathrm{i}}\right)+\mathrm{f}_{2}\left(\mathrm{x}_{2 \mathrm{i}}\right)+\ldots+\mathrm{f}_{\mathrm{k}}\left(\mathrm{x}_{\mathrm{ki}}\right)+\varepsilon_{\mathrm{i}}
$$

where $i$ indicates the ith hour's observation. $k$ refers to the type of impact factors. $f_{k}(x)$ are smooth functions of the data. The element $g\left(\mu_{\mathrm{i}}\right)$ is the "link" function, which specifies the relationship between the linear formulation on the right side of Equation (1) and the response $\mu_{\mathrm{i}}$. Nonlinear functions $\mathrm{f}_{\mathrm{k}}(\mathrm{x})$ are used to represent the complex relationship between ozone and impact factors. $\varepsilon_{\mathrm{i}}$ is the residual [47].

In this study, we considered hourly $\mathrm{O}_{3}$ concentration as the response variable, and hourly value of the relevant influencing factors, which were divided into environmental and meteorological factors in this study, as the explanatory variable. The GAM model check is mainly used to evaluate the quality of the proposed optimal model through the gam.check function in the $R$ language mgcv package. In addition, we used the adjusted $R^{2}$ and variance interpretation rate to evaluate the quality of the fitted GAM. The higher the adjusted $R^{2}$ and variance interpretation rate are, the better the model fitting effect are.

\section{Results}

\subsection{Characteristics of Ozone and Its Precursors during $\mathrm{O}_{3}$ Episodes}

$\mathrm{O}_{3}$ episodes with MAD8 greater than $160 \mu \mathrm{g} / \mathrm{m}^{3}$ are shown in Table S2. In total, 33 $\mathrm{O}_{3}$ episodes from 2018 to 2020 were analyzed in this study. The ozone concentration of $\mathrm{O}_{3}$ episodes in 2020 was $66.4 \mathrm{ppbv}$, which was higher than 2018 (61.9 ppbv) and lower than 2019 (75.5 ppbv). The frequency of $\mathrm{O}_{3}$ episodes were 15, 17, 4 and the number of days were 29, 28, and $5 \mathrm{~d}$ in 2018, 2019 and 2020, respectively (Figure 2). The longest duration of $\mathrm{O}_{3}$ episodes was 2 days in 2020, while the longest were $6 \sim 8 \mathrm{~d}$ in 2018 and 2019. The total hours of $\mathrm{O}_{3}$ episodes with an hourly value greater than $160 \mu \mathrm{g} / \mathrm{m}^{3}$ were 209,191 , and $30 \mathrm{~h}$, and the hourly peak concentrations were 344,258 and $211 \mu \mathrm{g} / \mathrm{m}^{3}$ in 2018, 2019 and 2020, respectively. The hourly peak concentrations in 2017 was observed 
$\left(279 \mu \mathrm{g} / \mathrm{m}^{3}\right)$ in the JJJUA [48]. The MAD8 peak concentration from 2014 to 2018 was observed $\left(297 \mu \mathrm{g} / \mathrm{m}^{3}\right)$ in Shijiazhuang [49]. It can be seen that although the value of ozone concentration in 2020 was not the lowest, the $\mathrm{O}_{3}$ episodes showed a decreasing trend in terms of pollution frequency, days, heavy pollution duration and peak concentration. This has a lot to do with the unprecedented reduction in air pollution emissions caused by the various containment measures taken by the Chinese government during the period of COVID-19 outbreak [50-52].
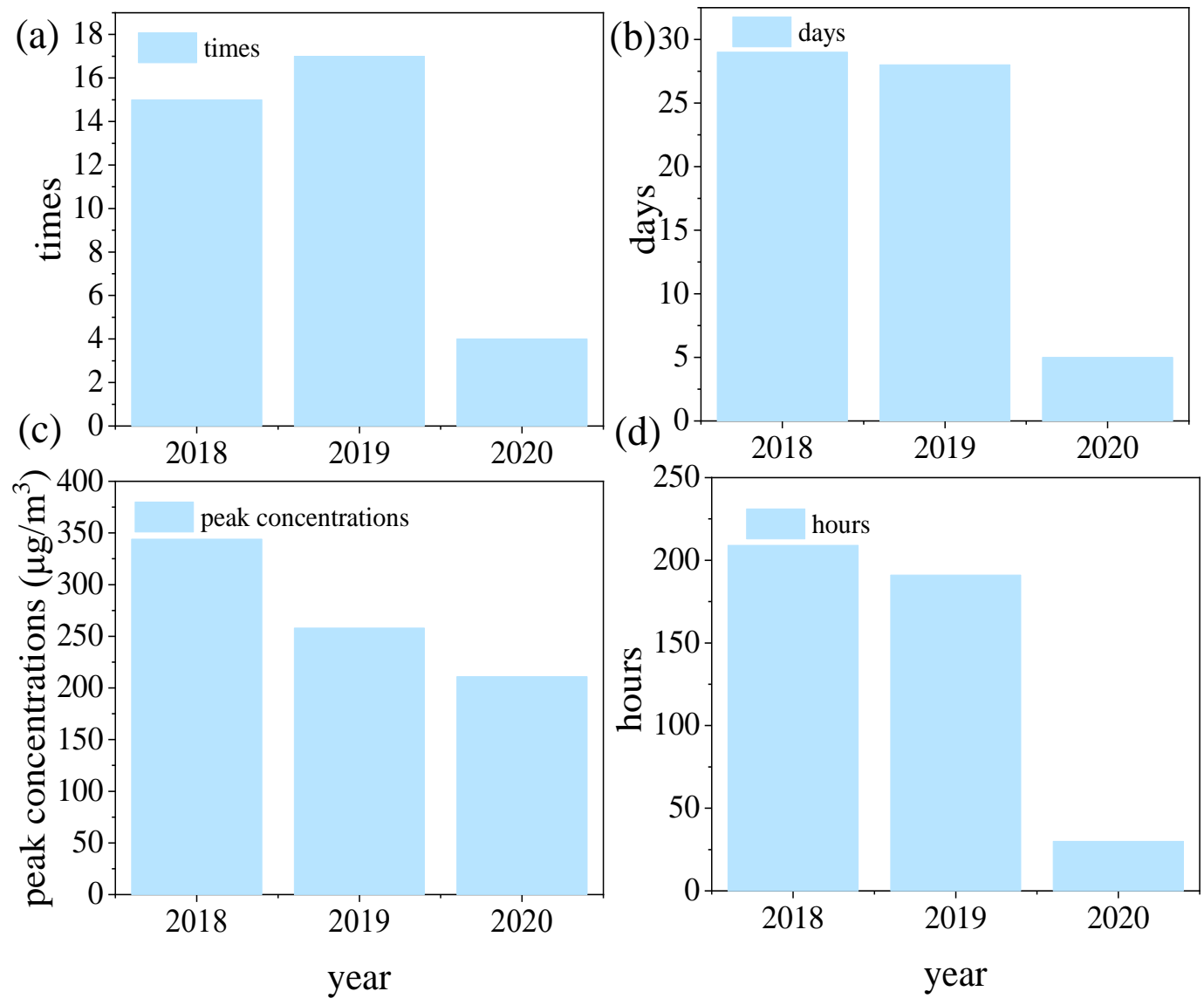

Figure 2. The frequency (a), the number of days (b), the hourly peak concentrations (c) and the total hours of $\mathrm{O}_{3}$ episodes with an hourly value greater than $160 \mu \mathrm{g} / \mathrm{m}^{3}$ (d) of $\mathrm{O}_{3}$ episodes in different years.

The average value of $\mathrm{NO}_{2}$ were 25, 19, and 15 ppbv during $\mathrm{O}_{3}$ episodes in 2018, 2019 and 2020, respectively, showing a decreasing trend. From the diurnal variation of pollutants during $\mathrm{O}_{3}$ episodes (Figure 3), we can see that $\mathrm{CO}$ and $\mathrm{SO}_{2}$ in 2020 were $1.7 \mathrm{ppbv}$ and $3.3 \mathrm{ppbv}$, respectively, which is significantly higher than previous years.

\subsection{Characteristics of VOCs and OFP during $\mathrm{O}_{3}$ Episode}

The highest concentration and proportion of alkanes were ethane (2.8 ppbv, 19.5\%), cyclopentane (2.4 ppbv, $16.8 \%$ ), methylcyclopentane ( $2.3 \mathrm{ppbv}, 15.9 \%)$, propane (1.6 ppbv, $11.3 \%$ ) and n-butane (1.3 ppbv, 8.9\%) during $\mathrm{O}_{3}$ episodes in 2020 (Figure S2). Propane (2.6 ppbv, 29.9\%) and ethane (1.9 ppbv, 21.8\%) were of the highest content during $\mathrm{O}_{3}$ episodes in 2018. The concentration of propane $(2.7 \mathrm{ppbv})$ was the highest, followed by cyclopentane, ethane, n-butane, i-pentane, and n-pentane during $\mathrm{O}_{3}$ episodes in 2019. Ethane and propane mainly come from incomplete combustion of motorcycles and motor vehicles [53] and liquefied petroleum gas/natural gas [54,55], and gasoline volatilization/emissions are characterized by high content of $C 4$ and $C 5$ alkanes [23]. $\mathrm{i} / \mathrm{n}$-pentanes were typical tracers for gasoline vehicle exhausts [56]. Cyclohexane can be released from diesel fuel evaporation [57]. Above all, among $\mathrm{O}_{3}$ episodes, LPG/natural 
gas emissions were important sources in 2018, and both LPG/natural gas and gasoline volatilization/emissions were important sources in 2019 and 2020.
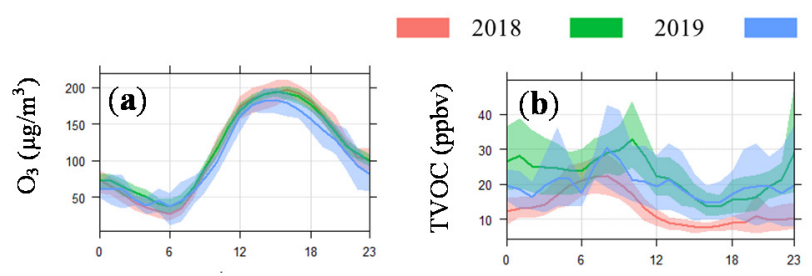

\section{0}
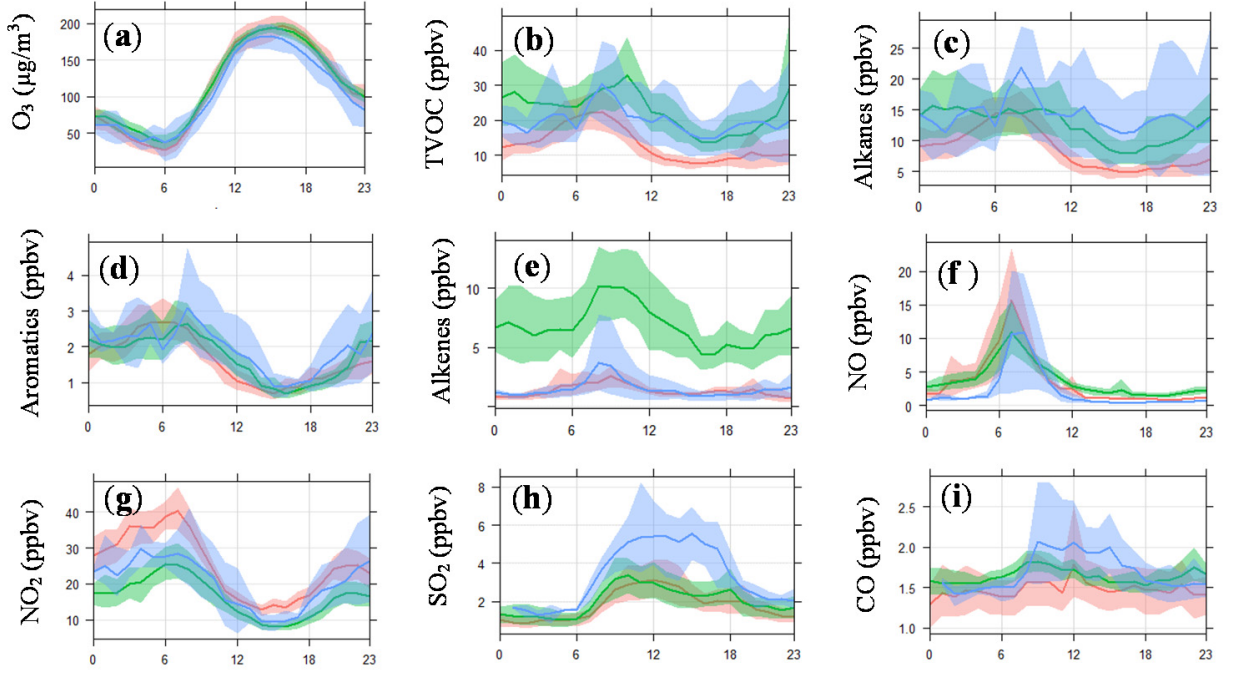

Hour (h)

Figure 3. Diurnal variations of pollutants during $\mathrm{O}_{3}$ episodes. (a) $\mathrm{O}_{3}$, (b) TVOC, (c) Alkanes, (d) Aromatics, (e) Alkenes, (f) $\mathrm{NO},\left(\right.$ g) $\mathrm{NO}_{2}$, (h) $\mathrm{SO}_{2}$, (i) CO.

The concentration and proportion of 1 -hexene $(0.5 \mathrm{ppbv}, 31.2 \%)$, ethylene $(0.3 \mathrm{ppbv}$, $22.8 \%$ ), and propene (0.3 ppbv, 21.9\%) were the highest among the alkenes during $\mathrm{O}_{3}$ episodes in 2020. 1-hexene (3.3 ppbv, 48.9.4\%), Styrene (1.5 ppbv, 22.1\%), isoprene (1.3 ppbv, 19.7\%), had the highest concentrations and proportions during $\mathrm{O}_{3}$ episodes in 2019. The concentration and proportion of propene ( $0.4 \mathrm{ppbv}, 34.1 \%)$, isoprene $(0.4 \mathrm{ppbv}, 32.8 \%)$, ethylene (0.3 ppbv, $24.8 \%)$ and cis-2-butene $(0.1 \mathrm{ppbv}, 13.4 \%)$ were the highest during $\mathrm{O}_{3}$ episodes in 2018. Ethylene and propene are important raw materials and products for rubber, plastics and other chemical manufacturing industries [58,59]. Isoprene was mainly derived from biological sources, indicating that rubber, plastics and other chemical manufacturing industries were important sources, and the impact of biological emissions may show a downward trend.

Toluene (0.7 ppbv, 34.6\%), benzene (0.6 ppbv, 29.6\%), and m,p-xylene (0.4 ppbv, 20\%) were major species among aromatics during $\mathrm{O}_{3}$ episodes in 2020. BTEX accounted for 91\% of aromatics, indicating that they were affected by vehicle emissions $[60,61]$ and solvent sources [62]. The concentrations and proportions of toluene $(0.6 \mathrm{ppbv}, 37.5 \%)$ and benzene (0.5 ppbv, 30.7\%) were the highest during $\mathrm{O}_{3}$ episodes in 2019, when BTEX accounted for $90 \%$ of aromatics. Toluene $(0.7 \mathrm{ppbv}, 42.0 \%)$, benzene $(0.5 \mathrm{ppbv}, 30.3 \%)$, m, p-xylene (0.2 ppbv, $12.7 \%)$ and ethylbenzene $(0.1 \mathrm{ppbv}, 8.9 \%)$ were major species among aromatics during $\mathrm{O}_{3}$ episodes in 2018, and BTEX accounted for $94 \%$ of aromatics. A toluene/benzene ratio lower than 2 indicates predominantly vehicular emissions, and a value greater than 2 was considered a complex emission source (motor vehicles, industry, solvent use). The toluene/benzene ratios during $\mathrm{O}_{3}$ episodes from 2018 to 2020 were $1.7 \pm 2.0,1.2 \pm 1.5$ and $1.5 \pm 2.1$, respectively, indicating that vehicular emissions were an important source.

The top ten substances of VOCs concentrations are shown in Figure 4. The major VOCs components during $\mathrm{O}_{3}$ episodes were essentially consistent in 2018 and 2020, and most of the components were low-carbon alkanes. During $\mathrm{O}_{3}$ episodes, propane, ethane, acetylene and i-pentane were the major species in 2018, and ethane, acetylene, cyclopentane and methylcyclopentane were the major species in 2020. Additionally, 1-hexene was the main component in 2019, followed by propane and cyclopentane. 


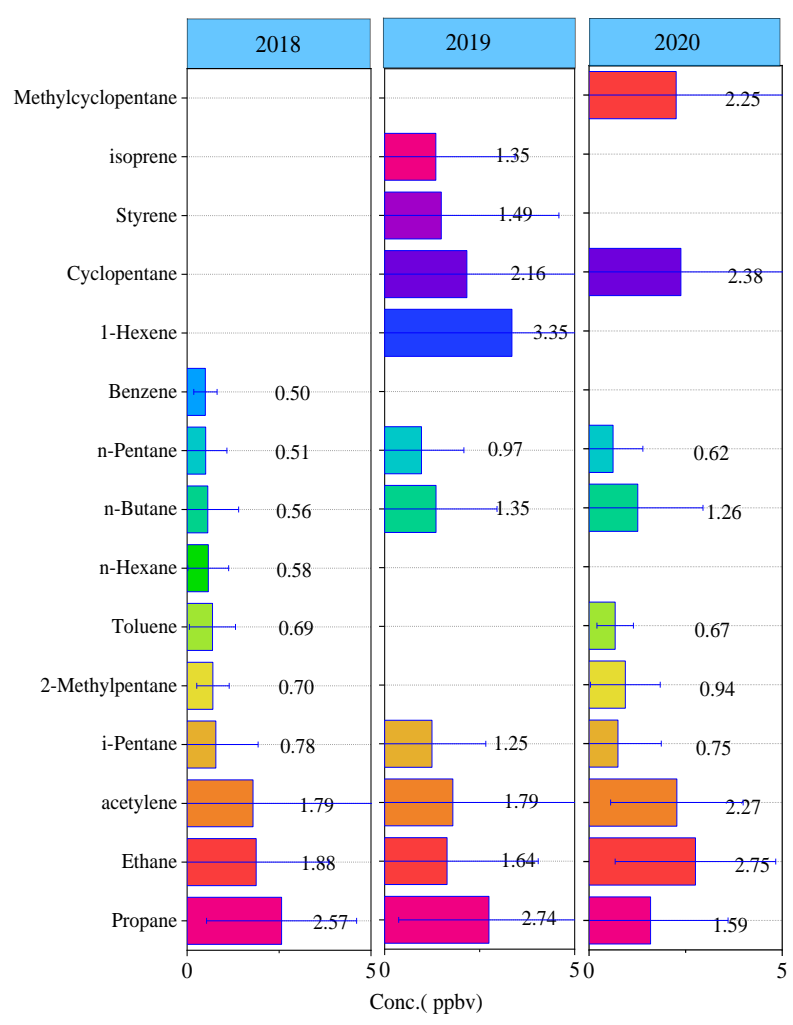

Figure 4. TOP 10 VOCs species in this study during $\mathrm{O}_{3}$ episodes.

The value of OFP during $\mathrm{O}_{3}$ episodes from 2018 to 2020 are shown in Figure S3. The top ten OFP species are shown in Figure S4, where the main ozone-contributing species were propene (4.68 ppbv), isoprene ( $4.08 \mathrm{ppbv})$, and ethylene ( $2.58 \mathrm{ppbv})$ in 2018 . The main ozone-contributing species in 2020 were propene (6.11 ppbv), cyclopentane (4.30 ppbv), methylcyclopentane (3.55 ppbv) and ethylene (3.18 ppbv), and alkenes were the important contributor to ozone formation. The top ten substances of OFP in 2019 were significantly different, and the main ozone-contributing species were 1-hexene (17.72 ppbv), isoprene (11.83 ppbv), propene (6.25 ppbv) and cyclopentane ( $4.83 \mathrm{ppbv})$.

During the $\mathrm{O}_{3}$ episodes in 2018 (Figure 5), the concentration of $\mathrm{O}_{3}$ was high from 12:00 to 19:00, and the concentration of propane and i-pentane in this period first decreased significantly, then increased sharply after 14:00, and then decreased and leveled off after 16:00. In 2019, the concentration of $\mathrm{O}_{3}$ was higher from 14:00 to 20:00, and the concentration of 1-hexene and propane first decreased significantly during this time period, then increased after 20:00. In 2020, the concentration of $\mathrm{O}_{3}$ was higher from 12:00 to 21:00; the concentration of methylcyclopentane first decreased significantly during this time period, and increased sharply after 16:00, then decreased and stabilized after 19:00, and acetylene increased sharply after 18:00. Other major VOCs species did not show an obvious trend during this period.

\subsection{Evaluation of the Influencing Factors on $\mathrm{O}_{3}$ Episodes}

Relevant research shows that the concentration of ozone is related to $\mathrm{CO}, \mathrm{SO}_{2}, \mathrm{NO}, \mathrm{NO}_{2}$, acetylene, alkenes, aromatics, alkanes, $\mathrm{wd}($ wind direction), $\mathrm{ws}$ (wind speed), $\mathrm{T}$ (temperature), $\mathrm{RH}$ (relative humidity), $\mathrm{P}$ (average air pressure), pre(precipitation), vis(visbility), TSRI(Total solar radiation intensity) and other influencing factors. Spearman's correlation analysis was conducted between hourly ozone and the corresponding influencing factors during $\mathrm{O}_{3}$ episodes from 2018 to 2020 (Figures S5-S7). The explanatory variables in the study are divided into environmental and meteorological factors. Environmental factors include $\mathrm{CO}$, $\mathrm{SO}_{2}, \mathrm{NO}, \mathrm{NO}_{2}$, acetylene, alkenes, aromatics and alkanes; meteorological factors include wd, ws, T, RH, P, Pre, TSRI, vis. A total of 16 impact factors were selected as explanatory 
variables, and $\mathrm{O}_{3}$ concentration as the response variable, whose distributions are all normal (Figure S8). The multifactor correlation analysis was carried out through the GAM model, and the effective data was totaled into 1475 groups.

(a)

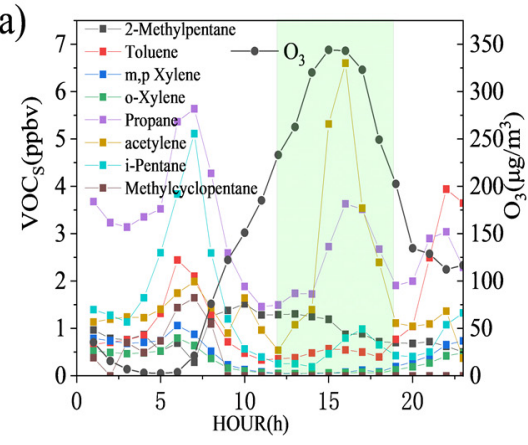

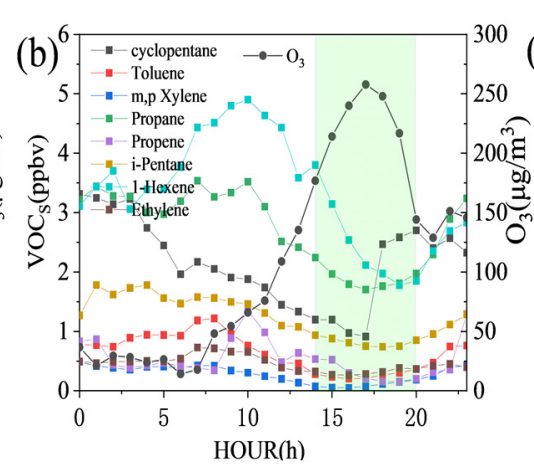

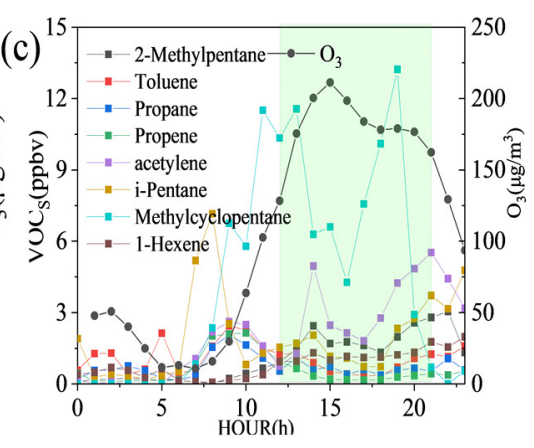

Figure 5. Diurnal variations of major VOCs and $\mathrm{O}_{3}$ during $\mathrm{O}_{3}$ episodes in 2018 (a), 2019 (b), 2020 (c).

Multivariate analysis showed that retention factor significantly affected the change of $\mathrm{O}_{3}$ concentration at the level of $p<0.001$, which was statistically significant. Factors that did not pass the significance analysis of TVOC were deleted, and $\mathrm{O}_{3}$ was taken as the explanatory variable used to reconstruct the multifactor GAM model until all variables passed the significance test. Factors which were included in the final GAM model in different years are listed in Table S3. The $\mathrm{R}^{2}$ of the multifactor GAM model during $\mathrm{O}_{3}$ episodes from 2018 to 2020 were $0.92,0.90$ and 0.98, respectively, and the deviances explained were $94 \%, 90.8 \%$ and $98.9 \%$. The model-fitting effect in Table S3 was better.

The gam.check function was used through the $\mathrm{mgcv}$ program package of $\mathrm{R}$ version 4.0.2 to evaluate the fitting effect of the multifactor model (Figures S9-S11). From the model residual QQ diagram, the points were approximately distributed in a straight line. From the residual histogram, the residual mean was close to 0 , and the frequency distribution was centered at 0 . The closer to 0 , the higher the frequency, and the two sides were essentially symmetrical. The model residuals were approximately normally distributed. From the scatter plot of residuals and predicted values, the points were essentially randomly distributed, indicating that the residuals were not related to the predicted values. Judging from the scatter plot of the observed values and the fitted values, the two basically had a straight-line distribution of $y=x$, indicating that the response variable after the model was fitted has a higher degree of matching with the fitted value. In conclusion, the multifactor model proposed in this paper had a good fitting effect.

The $\mathrm{F}$ value reflects the relative importance of each explanatory variable of the model to the dependent variable [63]. During $\mathrm{O}_{3}$ episodes in 2018, vis (16.6), $\mathrm{RH}$ (15.3), $\mathrm{NO}$ (14.3), and $\mathrm{T}$ (13.1) had the highest $\mathrm{F}$ value and had the greatest impact on $\mathrm{O}_{3}$. $\mathrm{T}(70.7), \mathrm{NO}_{2}(22.9)$, wd (22.8), and vis (21.9) had the highest $\mathrm{F}$ values in 2019 (Table S3). $\mathrm{T}$ (81.8), $\mathrm{NO}_{2}$ (39.8), vis (24.8), and ws (24.4) had the highest $\mathrm{F}$ values in 2020. It can be seen that $\mathrm{O}_{3}$ episodes were mainly driven by meteorological and precursor (NO) factors in 2018. $\mathrm{O}_{3}$ episodes were mainly driven by meteorological conditions (T), followed by precursor $\left(\mathrm{NO}_{2}\right)$, in 2019 and 2020.

Multifactor correlation analysis was performed through the GAM model to obtain the impact effect map of the influencing factors (Figure 6), and the specific influence of each influencing factor on $\mathrm{O}_{3}$ concentration were analyzed. T was the factor that had the greatest influence on $\mathrm{O}_{3}$ during $\mathrm{O}_{3}$ episodes in 2019 and 2020, which was much higher than other factors. $\mathrm{O}_{3}$ and $\mathrm{T}$ had a mainly nonlinear and positive correlation, with $\mathrm{O}_{3}$ episodes mainly occurring when $\mathrm{T}$ was greater than $20^{\circ} \mathrm{C}$, and ozone concentration increased with the rise of temperature. Further, there was an obvious inflection point, and when the temperature was higher, the increase in ozone concentration was more obvious, while the trend tends to be flat. In 2018 , the effect of T on ozone was not obvious at $20-35^{\circ} \mathrm{C}$, and the ozone concentration showed an increasing trend with the increase in temperature after 
$35^{\circ} \mathrm{C}$. High temperatures can enhance solar radiation and reduce cloud cover, which in turn increases the intensity of photochemical reactions, leading to an increase in ozone concentration [64].
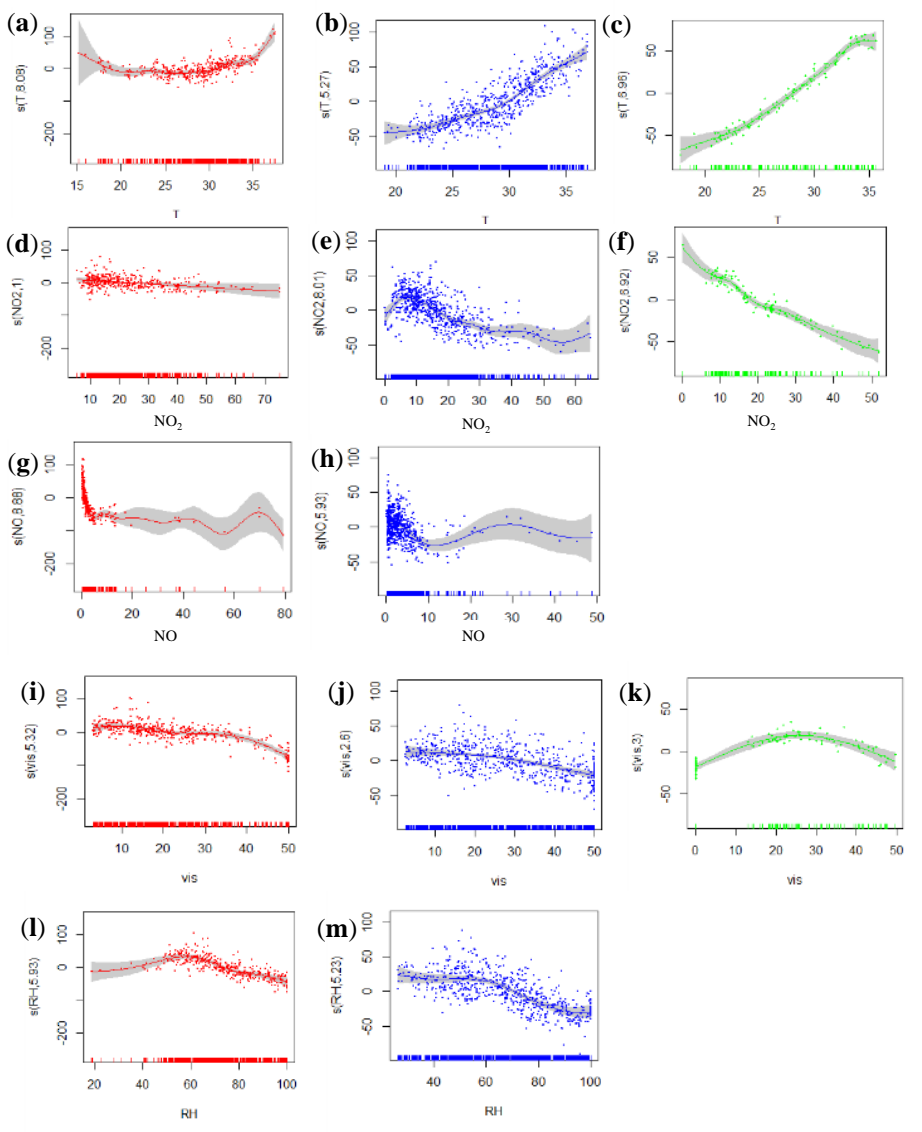

2018

2019

2020

Figure 6. Response curves of $\mathrm{O}_{3}$ concentration to changes in temperature in 2018 (a), 2019 (b), 2020 (c), $\mathrm{NO}_{2}$ concentration in 2018 (d), 2019 (e), 2020 (f), NO concentration in 2018 (g), 2019 (h), vis in 2018 (i), 2019 (j), 2020 (h) and RH in 2018 (l), 2019 (m), 2020 (k). The y-axis represents the smoothing function values; for example, $\mathrm{s}(\mathrm{T})$ shows the trend in $\mathrm{O}_{3}$ concentration when air temperature changes, and $\mathrm{df}$ is the degree of freedom for the trend. The $\mathrm{x}$-axis represents the measured values of the influencing factor, the solid curve indicates the trend in $\mathrm{O}_{3}$ concentration with the change of influencing factors, and the shaded area that is centered around the solid line indicates the CI (lower and upper limits) of $\mathrm{O}_{3}$ concentration.

$\mathrm{NO}_{2}$ was a factor that has a greater impact on $\mathrm{O}_{3}$ during $\mathrm{O}_{3}$ episodes in 2019 and 2020, second only to $\mathrm{T} . \mathrm{O}_{3}$ and $\mathrm{NO}_{2}$ were mainly nonlinear and negatively correlated, and the $\mathrm{O}_{3}$ concentration decreases with the increase of $\mathrm{NO}_{2}$ concentration, and the confidence interval of $\mathrm{NO}_{2}$ concentration was relatively narrow, indicating that there was a significant negative effect. NOx emission controls in China have been motivated mainly by the goal of decreasing nitrate $\mathrm{PM}_{2 \cdot 5}$, and further controls were expected in the future (http:/ / env.people.com.cn/n1/2020/0515/c1010-31710781.html, accessed on 20 August 2021). NO had a greater impact on $\mathrm{O}_{3}$ during $\mathrm{O}_{3}$ episodes in 2018 and 2019. When the NO concentration was lower than $10 \mathrm{ppbv}$, the $\mathrm{O}_{3}$ concentration showed a decreasing trend, but when the NO concentration was high, the overall impact trend was positive. This may be due to the role of $\mathrm{HO}_{2}$ in promoting the oxidation of $\mathrm{NO}$ to $\mathrm{NO}_{2}$ in the high-concentration environment [65], and photolysis generating $\mathrm{O}_{3}$ and increasing its concentration. Under certain conditions, nitrogen oxides, nitric oxide and VOCs generate 
ozone through photochemical reactions, which increase the ozone concentration and cause higher ozone pollution.

Vis was the factor that had the greatest impact on $\mathrm{O}_{3}$ during $\mathrm{O}_{3}$ episodes in 2018, and it also had a greater impact on $\mathrm{O}_{3}$ in 2019 and 2020. Visibility may be affected by several factors such as rain or thunderstorms, haze, fog and mist. The $\mathrm{O}_{3}$ concentration and vis were mainly nonlinear and negatively correlated in 2018 and 2019. As the vis increased, the $\mathrm{O}_{3}$ concentration gradually decreased. Vis showed a nonlinear, positive correlation at $10-20 \mathrm{~km}$ in 2020, and a nonlinear, negative correlation after $20 \mathrm{~km}$. RH was a factor that had a great impact on $\mathrm{O}_{3}$ during $\mathrm{O}_{3}$ episodes in 2018-it was second only to vis. The $\mathrm{O}_{3}$ concentration was mainly nonlinearly related to $\mathrm{RH}$. When $\mathrm{RH}<60 \%$, the effect of $\mathrm{RH}$ on $\mathrm{O}_{3}$ concentration did not change significantly; when $\mathrm{RH}>60 \%$, the $\mathrm{O}_{3}$ concentration decreased with the increase in $\mathrm{RH}$, and the decrease range was larger. TVOC (alkenes, aromatic hydrocarbons, alkynes, alkanes) had relatively low effects on $\mathrm{O}_{3}$ concentration, and some had not passed the GAM significance test. Compared with meteorological factors, their impact on ozone was very small.

\section{Conclusions}

1. $\mathrm{O}_{3}$ episodes from 2018 to 2020 were analyzed in this study, The ozone concentration of $\mathrm{O}_{3}$ episodes in 2020 was $66.4 \mathrm{ppbv}$, which was higher than 2018 (61.9 ppbv) and lower than 2019 (75.5 ppbv), although the value of ozone concentration in 2020 was not the lowest, the $\mathrm{O}_{3}$ episodes showed a decreasing trend in terms of pollution frequency, days, heavy pollution duration and peak concentration. The average value of $\mathrm{NO}_{2}$ during $\mathrm{O}_{3}$ episodes showed a decreasing trend, $\mathrm{CO}$ and $\mathrm{SO}_{2}$ in 2020 were $1.7 \mathrm{ppbv}$ and 3.3 ppbv, respectively, significantly higher than previous years.

2. The major VOCs components during $\mathrm{O}_{3}$ episodes were essentially consistent in 2018 and 2020, and most of the components were low-carbon alkanes. Propane, ethane, acetylene and i-pentane were the major species in 2018, ethane, acetylene, cyclopentane, and methylcyclopentane were the major species in 2020; 1-hexene was the main component in 2019. Above all, LPG/natural gas emissions were important sources in 2018, and both LPG/natural gas and gasoline volatilization/emissions were important sources in 2019 and 2020.

3. The main ozone-contributing species were propene ( $4.68 \mathrm{ppbv})$, isoprene ( $4.08 \mathrm{ppbv})$, and ethylene (2.58 ppbv) in 2018. The main ozone-contributing species in 2020 were propene $(6.11 \mathrm{ppbv})$, cyclopentane $(4.30 \mathrm{ppbv})$, methylcyclopentane $(3.55 \mathrm{ppbv})$ and ethylene (3.18 ppbv), and alkenes were important contributors to ozone formation. The top ten substances of OFP in 2019 were significantly different. The main ozone-contributing species were 1-hexene (17.72 ppbv), isoprene (11.83 ppbv), propene (6.25 ppbv) and cyclopentane (4.83 ppbv).

4. Based on the GAM results, $\mathrm{O}_{3}$ episodes was mainly driven by meteorological and precursor (NO) factors in 2018, while meteorological conditions (T), followed by precursor $\left(\mathrm{NO}_{2}\right)$ were the main driving factors in 2019 and 2020. Different factors had different driving impact on the $\mathrm{O}_{3}$ episodes. T had a nonlinear and positive impact, while $\mathrm{NO}_{2}$ had a nonlinear and negative impact.

Supplementary Materials: The following are available online at https:/ / www.mdpi.com/article/10 .3390 /atmos12111517/s1, Figure S1: Wind roses during study period in 2018(a), 2019(b), 2020(c) and during $\mathrm{O}_{3}$ episodes from 2018 to 2020(d), Figure S2: The mean concentrations of VOCs during the $\mathrm{O}_{3}$ episodes in this study, Figure S3:The mean OFP during the $\mathrm{O}_{3}$ episodes in this study, Figure S4: TOP 10 OFP species in this study during $\mathrm{O}_{3}$ episodes, Figure S5: The spearman correlation coefficients during $\mathrm{O}_{3}$ episodes in 2018, Figure S6: The spearman correlation coefficients during $\mathrm{O}_{3}$ episodes in 2019, Figure S7: The spearman correlation coefficients during $\mathrm{O}_{3}$ episodes in 2020, Figure S8: Density plot of $\mathrm{O}_{3}$, Figure S9: Residual error result test ((a) Residual QQ plot,(b) Residual histogram,(c) Scatter plot of residuals and predictions,(d) Scatter plot of observed and fitted values) in GAM model during $\mathrm{O}_{3}$ episodes in 2018, Figure S8: Density plot of $\mathrm{O}_{3}$, Figure S9: Residual error result test ((a) Residual QQ plot,(b) Residual histogram,(c) Scatter plot of residuals and predictions,(d) Scatter plot 
of observed and fitted values) in GAM model during $\mathrm{O}_{3}$ episodes in 2018, Figure S10: Residual error result test ((a) Residual QQ plot,(b) Residual histogram,(c) Scatter plot of residuals and predictions,(d) Scatter plot of observed and fitted values) in GAM model during $\mathrm{O}_{3}$ episodes in 2019, Figure S11: Residual error result test ((a) Residual QQ plot,(b) Residual histogram,(c) Scatter plot of residuals and predictions,(d) Scatter plot of observed and fitted values) in GAM model during $\mathrm{O}_{3}$ episodes in 2020. Table S1: Statistics analysis for meteorological parameters and pollutants during the the study period, Table S2: $\mathrm{O}_{3}$ episodes between 1th April, and 31th August from 2018 to 2020, Table S3: Estimated degree of freedom (Edf), degree of reference (Ref. df), P-value, F-value (which measures the relative importance of smoothed variable) for the smoothed variables in the GAM model.

Author Contributions: Writing—Original draft preparation, L.D.; Writing-Reviewing and Editing, X.B.; Reviewing and Revision, W.Z., B.L., Q.D.; Supervision and Reviewing, Y.Z., J.W., Y.F.; Data curation and investigation, X.W., L.L. All authors have read and agreed to the published version of the manuscript.

Funding: This research was funded by National Research Program for key issues in air pollution control (DQGG202102).

Institutional Review Board Statement: Not applicable.

Informed Consent Statement: Not applicable.

Data Availability Statement: Data is contained within the article or Supplementary Materials The data presented in this study are available in [insert article or Supplementary Materials here].

Conflicts of Interest: The authors declare no conflict of interest.

\section{References}

1. Silver, B.; Reddington, C.L.; Arnold, S.R.; Spracklen, D.V. Substantial changes in air pollution across China during 2015 to 2017. Environ. Res. Lett. 2018, 13, 114012. [CrossRef]

2. Adams, W.C. Effects of Ozone Exposure at Ambient Air Pollution Episode Levels on Exercise Performance. Sports Med. 1987, 4, 395-424. [CrossRef] [PubMed]

3. Chameides, W.L.; Kasibhatla, P.S.; Yienger, J.; Levy, H. Growth of Continental-Scale Metro-Agro-Plexes, Regional Ozone Pollution, and World Food Production. Science 1994, 264, 74-77. [CrossRef]

4. Feng, Z.; Hu, E.; Wang, X.; Jiang, L.; Liu, X. Ground-level O3 pollution and its impacts on food crops in China: A review. Environ. Pollut. 2015, 199, 42-48. [CrossRef]

5. Liu, H.; Liu, S.; Xue, B.; Lv, Z.; Meng, Z.; Yang, X.; Xue, T.; Yu, Q.; He, K. Ground-level ozone pollution and its health impacts in China. Atmos. Environ. 2017, 173, 223-230. [CrossRef]

6. Lefohn, A.S.; Malley, C.S.; Simon, H.; Wells, B.; Xu, X.; Zhang, L.; Wang, T. Responses of human health and vegetation exposure metrics to changes in ozone concentration distributions in the European Union, United States, and China. Atmos. Environ. 2016, 152, 123-145. [CrossRef]

7. Chameides, W.L.; Fehsenfeld, F.; Rodgers, M.O.; Cardelino, C.; Martinez, J.; Parrish, D.; Lonneman, W.; Lawson, D.R.; Rasmussen, R.A.; Zimmerman, P. Ozone precursor relationships in the ambient atmosphere. J. Geophys. Res. Atmos. 1992, 97, 6037-6055. [CrossRef]

8. Elminir, H.K. Dependence of urban air pollutants on meteorology. Sci. Total. Environ. 2005, 350, 225-237. [CrossRef]

9. Fiore, A.M.; Jacob, D.J.; Field, B.D.; Streets, D.G.; Jang, C. Linking ozone pollution and climate change: The case for controlling methane. Geophys. Res. Lett. 2002, 29, 25-1-25-4. [CrossRef]

10. Vingarzan, R. A review of surface ozone background levels and trends. Atmos. Environ. 2004, 38, 3431-3442. [CrossRef]

11. Ahamad, F.; Latif, M.T.; Tang, R.; Juneng, L.; Dominick, D.; Juahir, H. Variation of surface ozone exceedance around Klang Valley, Malaysia. Atmos. Res. 2014, 139, 116-127. [CrossRef]

12. Assareh, N.; Prabamroong, T.; Manomaiphiboon, K.; Theramongkol, P.; Leungsakul, S.; Mitrjit, N.; Rachiwong, J. Analysis of observed surface ozone in the dry season over Eastern Thailand during 1997-2012. Atmos. Res. 2016, 178-179, 17-30. [CrossRef]

13. Fu, J.S.; Dong, X.; Gao, Y.; Wong, D.C.; Lam, Y.F. Sensitivity and linearity analysis of ozone in East Asia: The effects of domestic emission and intercontinental transport. J. Air Waste Manag. Assoc. 2012, 62, 1102-1114. [CrossRef]

14. Lin, W.; Xu, X.; Zheng, X.; Dawa, J.; Baima, C.; Ma, J. Two-year measurements of surface ozone at Dangxiong, a remote highland site in the Tibetan Plateau. J. Environ. Sci. 2015, 31, 133-145. [CrossRef]

15. Cheng, H.R.; Guo, H.; Saunders, S.M.; Lam, S.H.M.; Jiang, F.; Wang, X.M.; Simpson, I.J.; Blake, D.R.; Louie, P.K.K.; Wang, T.J. Assessing photochemical ozone formation in the Pearl River Delta with a photochemical trajectory model. Atmos. Environ. 2010, 44, 4199-4208. [CrossRef]

16. Hu, R.; Liu, G.; Zhang, H.; Xue, H.; Wang, X. Levels, characteristics and health risk assessment of VOCs in different functional zones of Hefei. Ecotoxicol. Environ. Saf. 2018, 160, 301-307. [CrossRef] 
17. Zhang, D.C.; Liu, J.J.; Jia, L.Z.; Wang, P.; Han, X. Speciation of VOCs in the cooking fumes from five edible oils and their corresponding health risk assessments. Atmos. Environ. 2019, 211, 6-17. [CrossRef]

18. Cerqueira, M.A.; Pio, C.A.; Gomes, P.A.; Matos, J.S.; Nunes, T.V. Volatile organic compounds in rural atmospheres of central Portugal. Sci. Total Environ. 2003, 313, 49-60. [CrossRef]

19. Song, C.; Liu, Y.; Sun, L.; Zhang, Q.; Mao, H. Emissions of volatile organic compounds (VOCs) from gasoline- and liquified natural gas (LNG)-fueled vehicles in tunnel studies. Atmos. Environ. 2020, 234, 117626. [CrossRef]

20. Duan, J.; Tan, J.; Liu, Y.; Shan, W.; Hao, J. Concentration, sources and ozone formation potential of volatile organic compounds (VOCs) during ozone episode in Beijing. Atmos. Res. 2008, 88, 25-35. [CrossRef]

21. Ou, J.; Zheng, J.; Li, R.; Huang, X.; Zhong, Z.; Zhong, L.; Lin, H. Speciated OVOC and VOC emission inventories and their implications for reactivity-based ozone control strategy in the Pearl River Delta region, China. Sci. Total Environ. 2015, 530-531, 393-402. [CrossRef]

22. Cristofanelli, P.; Bonasoni, P. Background ozone in the southern Europe and Mediterranean area: Influence of the transport processes. Environ. Pollut. 2009, 157, 1399-1406. [CrossRef]

23. Li, K.; Chen, L.; Ying, F.; White, S.J.; Jang, C.; Wu, X.; Gao, X.; Hong, S.; Shen, J.; Azzi, M. Meteorological and chemical impacts on ozone formation: A case study in Hangzhou, China. Atmos. Res. 2017, 196, 40-52. [CrossRef]

24. Trainer, M.; Parrish, D.D.; Goldan, P.D.; Roberts, J.; Fehsenfeld, F.C. Review of observation-based analysis of the regional factors influencing ozone concentrations. Atmos. Environ. 2000, 34, 2045-2061. [CrossRef]

25. Wang, L.; Wang, W.J.; Wu, Z.; Du, H.; Shen, X.; Ma, S. Spatial and temporal variations of summer hot days and heat waves and their relationships with large-scale atmospheric circulations across Northeast China. Int. J. Climatol. 2018, 38, 5633-5645. [CrossRef]

26. Wang, Y.; Du, H.; Xu, Y.; Lu, D.; Wang, X.; Guo, Z. Temporal and spatial variation relationship and influence factors on surface urban heat island and ozone pollution in the Yangtze River Delta, China. Sci. Total. Environ. 2018, 631-632, 921-933. [CrossRef] [PubMed]

27. Cheung, V.; Wang, T. Observational study of ozone pollution at a rural site in the Yangtze Delta of China. Atmos. Environ. 2001, 35, 4947-4958. [CrossRef]

28. Jain, S.L.; Arya, B.C.; Kumar, A.; Ghude, S.D.; Kulkarni, P.S. Observational study of surface ozone at New Delhi, India. Int. J. Remote. Sens. 2005, 26, 3515-3524. [CrossRef]

29. Pulikesi, M.; Baskaralingam, P.; Rayudu, V.N.; Elango, D.; Ramamurthi, V.; Sivanesan, S. Surface ozone measurements at urban coastal site Chennai, in India. J. Hazard. Mater. 2006, 137, 1554-1559. [CrossRef]

30. Chen, X.; Liu, Y.; Lai, A.; Han, S.; Fan, Q.; Wang, X.; Ling, Z.; Huang, F.; Fan, S. Factors dominating 3-dimensional ozone distribution tropospheric ozone period. Environ. Pollut. 2018, 232, 55-64. [CrossRef]

31. Cardelino, C.A.; Chameides, W.L. An observation-based model for analyzing ozone precursor relationships in the urban atmosphere. J. Air Waste Manag. Assoc. 1995, 45, 161-180. [CrossRef] [PubMed]

32. Kova-Andri, E.; Brana, J.; Gvozdi, V. Impact of meteorological factors on ozone concentrations modelled by time series analysis and multivariate statistical methods. Ecol. Inform. 2009, 4, 117-122. [CrossRef]

33. An, J.; Wang, J.; Zhang, Y.; Zhu, B. Source Apportionment of Volatile Organic Compounds in an Urban Environment at the Yangtze River Delta, China. Arch Environ. Contam. Toxicol. 2017, 72, 335-348. [CrossRef]

34. Mozaffar, A.; Zhang, Y.; Fan, M.; Cao, F.; Lin, Y.C. Characteristics of summertime ambient VOCs and their contributions to O3 and SOA formation in a suburban area of Nanjing, China. Atmos. Res. 2020, 240, 104923. [CrossRef]

35. Gong, X.; Hong, S.; Jaffe, D.A. Ozone in China: Spatial Distribution and Leading Meteorological Factors Controlling O3 in 16 Chinese Cities. Aerosol. Air Qual. Res. 2018, 18, 2287-2300. [CrossRef]

36. Kim, J.H.; Hong, J. A GAM for Daily Ozone Concentration in Seoul. Key Eng. Mater. 2005, 277, 497-502. [CrossRef]

37. Chen, Z.; Zhuang, Y.; Xie, X.; Chen, D.; Cheng, N.; Yang, L.; Li, R. Understanding long-term variations of meteorological influences on ground ozone concentrations in Beijing During 2006-2016. Environ. Pollut. 2019, 245, 29-37. [CrossRef] [PubMed]

38. Lu, X.; Hong, J.; Zhang, L.; Cooper, O.R.; Schultz, M.G.; Xu, X.; Wang, T.; Gao, M.; Zhao, Y.; Zhang, Y. Severe Surface Ozone Pollution in China: A Global Perspective. Environ. Sci. Technol. Lett. 2018, 5, 487-494. [CrossRef]

39. He, Z.; Wang, X.; Ling, Z.; Zhao, J.; Guo, H.; Shao, M.; Wang, Z. Contributions of different anthropogenic volatile organic compound sources to ozone formation at a receptor site in the Pearl River Delta region and its policy implications. Atmos. Chem. Phys. 2019, 19, 8801-8816. [CrossRef]

40. Liu, H.; Zhang, M.; Han, X.; Li, J.; Chen, L. Episode analysis of regional contributions to tropospheric ozone in Beijing using a regional air quality model. Atmos. Environ. 2019, 199, 299-312. [CrossRef]

41. Lyu, X.; Wang, N.; Guo, H.; Xue, L.; Jiang, F.; Zeren, Y. Causes of a continuous summertime O3 pollution event in Jinan, a central city in the North China Plain. Atmos. Chem. Phys. 2019, 19, 3025-3042. [CrossRef]

42. Shao, P.; An, J.; Xin, J.; Wu, F.; Wang, J.; Ji, D.; Wang, Y. Source apportionment of VOCs and the contribution to photochemical ozone formation during summer in the typical industrial area in the Yangtze River Delta, China. Atmos. Res. 2016, 176-177, 64-74. [CrossRef]

43. Wang, T.; Xue, L.; Brimblecombe, P.; Lam, Y.F.; Li, L.; Zhang, L. Ozone pollution in China: A review of concentrations, meteorological influences, chemical precursors, and effects. Sci. Total Environ. 2017, 575, 1582-1596. [CrossRef] 
44. Wang, W.N.; Cheng, T.H.; Gu, X.F.; Hao, C.; Zhang, X.C. Assessing Spatial and Temporal Patterns of Observed Ground-level Ozone in China. Sci. Rep. 2017, 7, 1-12. [CrossRef]

45. Carter, W. Development of Ozone Reactivity Scales for Volatile Organic Compounds. Air Waste 1994, 44, 881-899. [CrossRef]

46. Carter, W. SAPRC Atmospheric Chemical Mechanisms and VOC Reactivity Scales. 2013. Available online: http://www.cert.ucr. edu/ \{\}carter/SAPRC/ (accessed on 20 August 2021).

47. Thompson, M.L.; Reynolds, J.; Cox, L.H.; Guttorp, P.; Sampson, P.D. A review of statistical methods for the meteorological adjustment of tropospheric ozone. Atmos. Environ. 2001, 35, 617-630. [CrossRef]

48. Wang, Z.-B.; Li, J.-X.; Liang, L.-W. Spatio-temporal evolution of ozone pollution and its influencing factors in the Beijing-TianjinHebei Urban Agglomeration. Environ. Pollut. 2020, 256, 113419. [CrossRef] [PubMed]

49. Wang, W.; Guo, W.; Cai, J.; Guo, W.; Liu, R.; Liu, X.; Ma, N.; Zhang, X.; Zhang, S. Epidemiological characteristics of tuberculosis and effects of meteorological factors and air pollutants on tuberculosis in Shijiazhuang, China: A distribution lag non-linear analysis. Environ. Res. 2021, 195, 110310. [CrossRef]

50. Huang, X.; Ding, A.; Gao, J.; Zheng, B.; Zhou, D.; Qi, X.; Tang, R.; Wang, J.; Ren, C.; Nie, W.; et al. Enhanced secondary pollution offset reduction of primary emissions during COVID-19 lockdown in China. Natl. Sci. Rev. 2020, 8, nwaa13. [CrossRef] [PubMed]

51. Li, L.; Li, Q.; Huang, L.; Wang, Q.; Zhu, A.; Xu, J.; Liu, Z.; Li, H.; Shi, L.; Li, R.; et al. Air quality changes during the COVID-19 lockdown over the Yangtze River Delta Region: An insight into the impact of human activity pattern changes on air pollution variation. Sci. Total Environ. 2020, 732, 139282. [CrossRef]

52. Xing, J.; Li, S.; Jiang, Y.; Wang, S.; Ding, D.; Dong, Z.; Zhu, Y.; Hao, J. Quantifying the emission changes and associated air quality impacts during the COVID-19 pandemic in North China Plain: A response modeling study. Atmos. Chem. Phys. 2020, 20, 14347-14359. [CrossRef]

53. Guo, H.; Wang, T.; Louie, P.K.K. Source apportionment of ambient non-methane hydrocarbons in Hong Kong: Application of a principal component analysis/absolute principal component scores (PCA/APCS) receptor model. Environ. Pollut. 2004, 129, 489-498. [CrossRef] [PubMed]

54. Blake, D.R.; Rowland, F.S. Urban Leakage of Liquefied Petroleum Gas and Its Impact on Mexico City Air Quality. Science 1995, 269, 953-956. [CrossRef]

55. Ling, Z.H.; Guo, H.; Cheng, H.R.; Yu, Y.F. Sources of ambient volatile organic compounds and their contributions to photochemical ozone formation at a site in the Pearl River Delta, southern China. Environ. Pollut. 2011, 159, 2310-2319. [CrossRef]

56. Ho, K.F.; Lee, S.C.; Ho, W.K.; Park, D. Vehicular Emission of Volatile Organic Compounds (VOCs) from a Tunnel Study in Hong Kong. Atmos. Chem. Phys. 2009, 9, 7491-7504. [CrossRef]

57. Liu, Y.; Shao, M.; Fu, L.L.; Lu, S.H.; Zeng, L.M.; Tang, D.G. Source profiles of volatile organic compounds (VOCs) measured in China: Part I. Atmos. Environ. 2008, 42, 6247-6260. [CrossRef]

58. Ling, Z.H.; Guo, H. Contribution of VOC sources to photochemical ozone formation and its control policy implication in Hong Kong. Environ. Sci. Policy 2014, 38, 180-191. [CrossRef]

59. Jobson, B.T.; Berkowitz, C.M.; Kuster, W.C.; Goldan, P.D.; Williams, E.J.; Fesenfeld, F.C.; Apel, E.C.; Karl, T.; Lonneman, W.A.; Riemer, D. Hydrocarbon source signatures in Houston, Texas: Influence of the petrochemical industry. J. Geophys. Res. Atmos. 2004, 109. [CrossRef]

60. Bari, M.A.; Kindzierski, W.B.; Wheeler, A.J.; Héroux, M.-È.; Wallace, L.A. Source apportionment of indoor and outdoor volatile organic compounds at homes in Edmonton, Canada. Build. Environ. 2015, 90, 114-124. [CrossRef]

61. Mo, Z.; Shao, M.; Lu, S. Compilation of a source profile database for hydrocarbon and OVOC emissions in China. Atmos. Environ. 2016, 143, 209-217. [CrossRef]

62. Song, C.; Liu, B.; Dai, Q.; Li, H.; Mao, H. Temperature dependence and source apportionment of volatile organic compounds (VOCs) at an urban site on the north China plain. Atmos. Environ. 2019, 207, 167-181. [CrossRef]

63. Camalier, L.; Cox, W.; Dolwick, P. The effects of meteorology on ozone in urban areas and their use in assessing ozone trends. Atmos. Environ. 2007, 41, 7127-7137. [CrossRef]

64. Cao, T.; Kai, W.U.; Kang, P.; Wen, X.; Han, L.I.; Wang, Y.; Xinyuan, L.; Anqi, L.I.; Pan, W.; Fan, W. Study on ozone pollution characteristics and meteorological cause of Chengdu-Chongqing urban agglomeration. Acta Sci. Circumstantiae 2018, 38, 1275-1284.

65. Tang, X.Y.; Zhang, Y.H.; Shao, M. Atmospheric Environmental Chemistry [M]; Higher Education Press: Beijing, China, 2006; pp. 407-409. 